\title{
4 Ceará, Lado Moleque (As Letras e a Sociogênese do Humor)
}

* Andréa Borges Leão é socióloga e professora do Departamento de Ciências Sofescre do Deprta de Pós-Grências so-

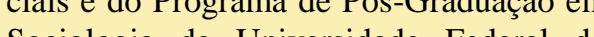
Sociologia da Universidade Federal do Ceará; Francisco Secundo é sociólogo doutorando no mesmo Programa.

Andréa Borges Leão e Francisco Secundo*

Resumo: $\mathrm{O}$ artigo discute as definições de que se reveste o termo "Ceará moleque", desde a literatura e movimentos intelectuais de fins do século XIX à crítica cultural dos anos 1930. A hipótese é de que as várias circunstâncias e disposições do termo descrevem uma sociogênese do humor cearense, formando o legado do que hoje se entende como produção cultural do entretenimento. Para tanto, começa pelo anedotário do poeta Paula Nei, sua prática literária e política no movimento abolicionista. Em seguida, acompanha as disposições gaiatas dos homens de letras nos grêmios literários, como a Padaria Espiritual, uma experiência mais informal e um tanto moderna avant la lettre. A leitura das obras de Oliveira Paiva e Adolfo Caminha nas quais o termo "Ceará moleque" é definido vem logo após, junto às tentativas de explicação da cearensidade na crítica cultural dos anos trinta.

Palavras-chave: Ceará moleque; sociogênese; literatura e humor; cultura e entretenimento
Abstract: This article analyzes the different definitions of the term "Ceará Moleque", from literature and intellectual movements in the end of the 19th century up to the cultural critique of the 1930s and contemporary uses. The hypothesis is that the several circumstances and dispositions of the term describe a sociogenesis of the cearense humor, creating the legacy of which today is understood as cultural production of entertainment. With this purpose, the anecdote from the poet Paula Ney is chosen for its literary practice and politics in the abolicionist movement. This article follows the disposition of men in the literature associations such as Padaria Espiritual, a more informal and also quite modern experience avant la lettre. The reading of Paiva's and Adolfo Caminha's work in which the term "Ceará Moleque" is defined comes right after, with the attempts of explaining "cearensidade" as self-image.

KeyWords: "Ceará moleque"; sociogenesis of humor; literature and humor; culture and entertainement. 
1 Segundo Gleudson Passos Cardoso (2002), coube ao Instituto do Ceará, criado em 1887, a investigação e interpretação dos "traços identitários do povo cearense". Contudo, os poetas e literatos de Fortaleza também tomaram para si tal missão nos seus escritos, como Oliveira Paiva e Adolfo Caminha.

${ }^{2}$ A novela, anos mais tarde, entre janeiro e outubro de 1929, é publicada na Revista da Academia Brasileira de Revista da Academia Brasileira de
Letras, mas com um título diferente: $O$ Cajueiro do Fagundes (episódio cearense). E é com este título, no ano de 1975, que o romance ganha uma edição em livro pela Secretaria de Cultura, Desporto e Promoção Social de Fortaleza.

\section{Introdução}

\section{Sociogênese do humor}

A expressão "Ceará moleque" aparece em dois romances de finais do século XIX: A Afilhada, de Manuel de Oliveira Paiva, publicado em 1889 no jornal O libertador, de Fortaleza; e A Normalista, de Adolfo Caminha, publicado no Rio de Janeiro, em 1893. Os enredos fazem uma crítica de costumes da sociedade fortalezense. Oliveira Paiva e Adolfo Caminha descrevem a psicologia do gênio e o espírito dos habitantes da capital da Província. Os dois tinham a pretensão de identificar e demonstrar uma espécie de "caráter cearense"" O rótulo "Ceará moleque" não traduzia propriamente a imagem de um povo irreverente e alegre, como nos dias de hoje em que Fortaleza é uma cidade ilustrada pelo humor. Na crítica social das obras, era sinônimo de atraso nas atitudes e ideias, falta de nobreza (polidez) e canalhice, significando a exposição pública da vida alheia (mexerico e maledicência).

Não se pode afirmar, entretanto, que a expressão "Ceará moleque" tenha aparecido pela primeira vez nos romances-folhetins. Certamente de domínio público, tinha a função de alcunha e circulava entre a fala e os impressos. Tudo leva a crer que o adjetivo moleque e o nome molecagem foram utilizados no linguajar cotidiano e, até, citados nas conversas entre os intelectuais cearenses que gostavam de contar piada. A literatura apenas confere visibilidade a algo que transitava com desenvoltura nos circuitos populares da cidade.
Após as primeiras aparições no romance, o "Ceará moleque" marca presença em outras publicações, que na sua maioria evocavam significados próximos aos de canalhismo e falta de nobreza, caso do pasquim que se auto-intitulava, em 1897, Ceará Moleque - Revista Caricata.

Em 1911, o Jornal do Comércio, do Rio de Janeiro, publica em folhetim a novela Um Motim na Aldeia, assinada por Cosme Velho, pseudônimo de Tristão de Alencar Araripe Júnior ${ }^{2}$. Esta novela, em 1929, é publicada na Revista da Academia Brasileira de Letras com o título $O$ Cajueiro do Fagundes (episódio cearense). A molecagem nacionalizada na imprensa carioca torna-se ingrediente na construção de um passado que estaria na origem do "povo cearense" e, por conseguinte, da invenção do Ceará.

Com Araripe Júnior inicia-se a idealização do mito da molecagem, ressaltando-se que isso não implica a dissipação do sentido pejorativo atribuído anteriormente. Por muitos anos, o "Ceará moleque" ainda evocaria a canalha. A quem se qualificaria como moleque? As classes populares ou todos aqueles que de alguma maneira não observavam as regras de conduta e decoro de uma sociedade civilizada. A molecagem seria como a natureza da gente do povo, chamada também de "arraia miúda", "povo chinfrim" e "canalha", traduzindo, conforme Silva (2003), a imaginação dos pobres e iletrados.

No entanto, uma série de cronistas do século XX passa a remeter o epíteto às figuras nobres, a homens de letras na sua maioria. Renato Sóldon, sobrinho do poeta e advogado Quintino Cunha, publica em 1936 o livro Ceará Moleque (humorismo cearense), no qual

Dossiê Literatura e Memória 


\section{Andréa Borges Leão}

Francisco Secundo

elenca uma miríade de personalidades como protagonistas de causos pitorescos e anedóticos. Da prática de insulto o termo passa a qualificar as práticas do riso e da galhofa. Antes as pessoas que o utilizavam sentiam vergonha delas mesmas e apontavam defeitos nos outros, agora, os intelectuais-moleques contadores de piadas riem deles mesmos e sem culpa. Dentre os "ilustres cearenses" do livro de Sóldon, caricaturas da molecagem, figuram Gustavo Barroso (romancista, membro da Academia Brasileira de Letras e um dos primeiros diretores do Museu Histórico Nacional), João Brígido (jornalista e cronista), Leonardo Mota (jornalista e folclorista), Paula Nei (poeta e ativista político) e o tio do autor, o poeta Quintino Cunha. Os ditos espirituosos (mot d'esprit), as piadas e ironias ligadas à sutileza intelectual desses escritores que faziam rir permitem daí em diante a valorização da molecagem como um dos traços positivos de cearensidade. No correr do tempo, as práticas do humor adquirem legitimidade, os humoristas se profissionalizam e é organizada uma indústria cearense do riso.

Este artigo estuda as mutações de que se reveste o termo "Ceará moleque", desde a literatura e dos movimentos intelectuais em Fortaleza de fins do século XIX à crítica cultural dos anos trinta. As várias circunstâncias e disposições do termo convivem em concorrências, ora associando o humor à calunia, ora aproximando-o da subversão ou da simples brincadeira. Seguimos a hipótese de que as apropriações do "Ceará moleque" acabam descrevendo a sociogênese de um humorismo particular ao Ceará. O movimento de mais de um século constitui o legado da atual produção cultural do entretenimento.
Antes de iniciarmos é necessário dizer algo a respeito do conceito de sociogênese e do modo como o apreendemos. Na caixa de ferramentas do sociólogo Norbert Elias (1990), a sociogênese indaga a ordem e a direção subjacente às mudanças nas interdependências humanas. Em longos processos de estruturação, a civilização ocidental passa por transformações especificamente orientadas em direção a um maior controle social nos padrões de comportamento e a uma maior contenção nas operações afetivas dos indivíduos. Os caminhos das mudanças tem como efeito a alteração na ordem das proibições, nos patamares de vergonha e medo e nos modos de diversão e entretenimento. O alcance da reflexão de Elias e Dunning (1995) sobre o esporte e o lazer como momentos de distensão controlada da civilização nos leva aos pontos de tensão ocasionados pelo bom ou mau riso. As lutas de representação do "Ceará Moleque" ao ativarem sentimentos de inferioridade e de superioridade se inscrevem de modo singular na dinâmica civilizatória, articulando processos de integração social às mudanças na economia psíquica dos indivíduos.

Note-se ainda que as definições concorrentes da molecagem são ao mesmo tempo simultâneas e sucessivas. A tendência civilizatória identificada por Cas Wouters (2007) de informalização dos costumes e emancipação das emoções é uma outra importante orientação de leitura. Para Wouters, as emoções negadas e reprimidas pelos processos de controle social típicos dos séculos precedentes conquistam maior aceitação nos códigos de conduta do século $\mathrm{XX}$, ao mesmo tempo em que ganham acesso ao nível da consciência dos indivíduos, tornando-os menos rígidos e mais flexíveis em manejá-

Dossiê Literatura e Memória 
${ }^{3}$ Tomamos como referência as biografias de Menezes, 1944; e Cunha 1949. las. Observamos que as gramáticas sociais específicas nas quais vai se enquadrando a molecagem proporcionam estados de excitação tolerados e aceitos coletivamente.

Para melhor apreender as reviravoltas históricas do estilo moleque, o artigo começa por recompor o destino do poeta Francisco de Paula Nei. A vida boêmia, a declamação de versos e a atuação política de Nei no movimento abolicionista foram a "pedra de toque" para a construção de um anedotário próprio aos escritores cearenses. Em seguida, acompanha as disposições gaiatas dos homens de letras nos grêmios literários de Fortaleza, como a Padaria Espiritual, uma experiência um tanto moderna avant la lettre. A leitura das obras de Oliveira Paiva e Adolfo Caminha, nas quais se define o termo "Ceará moleque", vem logo após, junto às tentativas de explicação da cearensidade como autoimagem.

\section{O que descortinam as piadas de Paula Nei?}

Em fins do século XIX, Francisco de Paula Nei liderava a boêmia carioca, improvisando sonetos e seguindo os mexericos da política pela vida mundana. Jornalista de profissão, apanhava a meada da intriga e, na manhã seguinte, a materia circulava por todo o Rio de Janeiro. Depois de passar o dia tomando notas, à tardinha ditava-as às pressas aos redatores do jornal Gazeta de Notícias. Nei foi o mais hábil reporter mundano de seu tempo e tornou-se popular pelo gosto em fazer rir. Inventou um ofício na arte de brincar com as palavras e com elas fazer trocadilhos de humor, chistes e sátiras contra os políticos e os escritores consagrados a quem, diz Eloy Pontes (1944), chamava de "fósseis literatos".

A vida de Paula $\mathrm{Nei}^{3}$ é a expressão das disputas e anseios profissionais de uma geração de escritores situados nas margens do mundo literário e que, portanto, não obtiveram o reconhecimento de suas obras. Mesmo que a circulação da cultura impressa não se restringisse aos espaços canônicos das faculdades de medicina e direiro, das academias literárias, dos grêmios e bibliotecas, e ocupasse as mesas dos cafés e botecos, os boêmios permaneceram nas margens. Mas os circuitos da oralidade insistiam em permanecer neste panorama cultural que ainda não contava com uma industria editorial dos impressos.

Era possível que poetas como Nei não se empenhassem em publicar livros; do modo como viviam só lhes restava escrever sobre as toalhas das mesas das confeitarias, rabiscar versos nos quardanapos, recitar poemas na roda dos amigos, eventualmente publicar reportagens nos jornais. Ainda assim, em 1887, dez anos antes da inauguração da Academia Brasileira de Letras, Paula Nei em companhia de Olavo Bilac, José do Patrocínio, Coelho Neto e Guimarães Passos, foi o idealizador do Grêmio de Letras e Artes. O Grêmio era um dos pontos de partida para a discussão coletiva sobre a carreira e a remuneração da litertaura, criando as bases para o reconhecimentos dos direitos autorais.

Se as quadrinhas improvisadas corriam de boca em boca não quer dizer que fossem conservadas para a posteridade. Nei pouco 


\section{Andréa Borges Leão}

\section{Francisco Secundo}

escreveu. Considerava-se mais um folhetinista oral do que homem da pena. Vale a pena conhecer um pouco da sua biografia.

Franciso de Paula Nei, filho do alfaiate Mariano de Melo Nei e de Carlota Cavalcanti de Sousa Pinheiro, nasceu no dia 02 de fevereiro de 1858, na Vila do Aracati, litoral do Ceará. Estudou no Ateneu Cearense, colégio do professor Costa Mendes inspirado no modelo pedagógico do Ateneu Baiano, do Barão de Macaúbas. Durante os três anos passados no Ateneu, Nei conheceu Domingos Olimpio, futuro autor de Luzia-Homem, Rodolfo Teófilo, que escreveria o romance $A$ fome sobre a seca de 1877 no Ceará e João Capistrano de Abreu, futuro historiador. Em 1873, Paula Nei continua os estudos no Seminário Episcopal e, de lá, faz os exames preparatórios no Liceu do Ceará.

No Seminário, a disciplina da vida eclesiástica não combinava com o comportamento estouvado e brincalhão do poeta. Escolhido para representar junto ao reitor um caso de humilhação sofrida por um colega, convocou os seminaristas para ir ao auditório, discursou em nome da liberdade, da justiça e da solidariedade. Esse discurso lhe valeu a expulsão da escola e castigos físicos do pai. Nei foi ao delegado de policia registar queixa contra o pai pelo castigo infligido. Não poderia ser diferente no Liceu do Ceará, onde adquiriu uma cultura literária e participou do Gabinete Cearense de Leitura, formado pelos estudantes. Em 1876, entrou em rota de colisão com um professor de inglês, discordando do método de ensino. Na rua, continuou a enfrentar o professor com quadrinhas engraçadas, o que lhe valeu a reprovação na matéria. Esta circusntância apressou a sua viagem para o Rio de Janeiro.

Na corte, onde chegara em princípios de 1877, entrou para o Colégio Pedro II, prestou exame de inglês, no qual foi aprovado. Sua primeira pilhéria carioca, nos conta Ciro Vieira da Cunha (1949), foi retirar mais três cerificados de exames de inglês: um para a matrícula no curso superior da Escola de Engenharia do Rio de Janeiro, outro para seu pai e o último enviou ao professor de inglês do Liceu Cearense, com uma dedicatória jocosa.

Após concluir os exames no Colégio Pedro II, o poeta matricula-se na Escola de Engenharia. No primeiro dia de aula, após mais um desentendimento com o professor de cálculo, que lhe passara um problema cuja conclusão era nula, usou uma pilhéria, saiu e nuca mais voltou. Efetuou, então, sua matrícula na Faculdade de Medicina, onde iniciou o elenco das piadas que corriam de boca em boca. Como precisava conciliar os estudos com o trabalho, Nei arrumou um emprego de repórter policial, após recitar uns versos ao diretor da Gazeta de Notícias, Ferreira Araújo. Na Gazeta, conheceu muitos jornalistas e intelectuais, como José do Patrocínio. Uma feita, Patrocínio, que mais tarde viajaria para conhecer a libertação dos escravos no Ceará, fez uma conferência relâmpago sobre o abolicionismo. O cearense de pronto aderiu e passou a ser discípulo do "Tigre da Abolição".

$\mathrm{Na}$ Faculdade de Medicina, os biógrafos citam as seguintes tiragens engraçadas da lavra de Paula Nei, durante os exames, cara a cara com os professores: "- Diga ao mestre Sr. Nei, quantos ossos 


\section{Andréa Borges Leão}

\section{Francisco Secundo}

tem o crânio de um homem? - Não me recordo professor, mas tenho-os todos aqui na cabeça".

E numa uma sabatina de anatomia,

- Sr. Nei, vou fazer a primeira pergunta e, se o senhor responder, não lhe farei a segunda, dando-me por satisfeito:

- Quantos fios de cabelos tem o senhor? quatro

- Duzentos e sessenta e cinco mil oitocentos e noventa

- Mas como o Sr. chegou a esta conclusão?

- Caro professor, não se esqueça que o Sr. garantiu que só faria uma pergunta. Trato é trato!

Coelho Neto, em A Conquista (1899), lembra que no dia marcado para o exame final do ano de 1880, a sala da Faculdade estava repleta de uma plateia sedenta pelas respostas espirituosas de Paula Nei. Era uma arguição de obstetrícia, o candidato devia se imaginar parteiro. O catedrático simulou a situação de um parto complicado, a mãe e a criança correndo perigo, o que faria ele? Nei, por trás do pince-nez de míope que lhe dava ares preocupados, não titubeou: “Pedia o auxílio de um tilburi e mandava chamar V. Excia”. O auditório explodiu às gargalhadas. Mais uma vez, o poeta foi reprovado, mas não perdeu a rima, zarpou para Salvador, a fim de concluir o curso na Escola de Medicina da Bahia.

$\mathrm{Na}$ Bahia, foi mais uma vez reprovado. De volta ao Rio de Janeiro, Paula Nei perderia o interesse pelos estudos, mergulhando nas lides da imprensa e na roda-viva não menos desgastante da vida boêmia. O grupo boêmio-literário de José do Patrocínio e Paula Nei reunia-se nas mais badaladas confeitarias da época - a Deroche, a Colombo, a Cailteau, a Pascoal - e compunha-se dos escritores Pardal
Mallet, Lopes Trovão, Guimarães Passos, Olavo Bilac, Coelho Neto, Luiz Murat, Plácido Júnior, Emílio de Menezes, Pedro Rabelo, entre outros. Juntos urdiam a aura ou a desgraça de um poeta, tramavam enredos para um romance em autorias e pseudônimos compartilhados e perpetravam os indefectíveis sonetos de amor. Os donos das confeitarias faziam as vezes de patronos, fechando os olhos para as dívidas e emprestando dinheiro. Não se pode negar que o trabalho na imprensa, as bebedeiras e recitação de versos são os princípios definidores da geração literária de 1880.

Em 1897, era inaugurada a Academia Brasileira de Letras. Machado de Assis e Medeiros e Albuquerque organizaram uma lista de quarenta nomes para compor os imortais. Por causa das bombásticas declamações nos grupos de amigos e das inovações nos padrões de escrita, o humorismo provocava desconfiança. Paula Nei ficou de fora da lista, apesar do seu trabalho na organização do Grêmio de Letras e Artes. Alguns dos eleitos eram seus amigos, muitos aplaudiram as suas piadas, desfrutaram de sua companhia nos teatros e confeitarias, mas para a Academia apresentavam restrições ao nome do folhetinista oral amigo da pena.

Nem só de piadas e aplausos viveu o cearense do Rio de Janeiro. Seu humor e talento oratório foram bem aproveitados a favor do movimento abolicionista no Brasil. Nei escreveu artigos para os jornais e discursou em comícios de rua. Sobre o 13 de maio de 1888 , improvisou um soneto intitulado $A$ abolição.

Em 1878, José do Patrocínio viajou para o Ceará como repórter da Gazeta de Notícias, a fim de cobrir a seca e a situação dos reti- 


\section{Andréa Borges Leão}

Francisco Secundo

rantes na capital. Praticava o que se chamava de imprensa viva - a observação direta, primando pela descrição fiel dos fatos. Dessa viagem, na qual viu todos os flagelos, da fome à prostituição, escreveu um romance chamado Os retirantes, publicado na Gazeta de Notícias, em folhetim. Em 1882, retornava a Fortaleza para celebrar a ação abolicionista de João Cordeiro, Frederico Borges, José Correia do Amaral, Almino Álvares Afonso, José Teles Marrocos e outros ativistas que formavam a Cearense Libertadora e a Perseverança e Porvir.

No Ceará, devido ao recrudescimento da campanha e à fuga de escravos, os proprietários resolveram vender os seus negros para os fazendeiros do sudeste, mas os jangadeiros se recusavam a fazer o transporte para os navios-negreiros. Francisco José do Nascimento, o Chico da Matilde, em 27 de agosto de 1881, determinou que não se embarcavam mais escravos nos portos do Ceará. Patrocínio entusiasmava-se com essas notícias recebidas na Corte. Para ele, o Ceará passou a ser a "Terra da Luz", e para os cearenses abolicionistas do mar, ele foi um "Marechal Negro".

Afirma Raimundo de Menezes (1944) que Paula Nei acompanhou Patrocínio na viagem. Já para o autor de $A$ vida turbulenta de José do Patrocínio (1969), Magalhães Júnior, Patrocínio embarcou na companhia de Alípio Teixeira, que trabalhava como representante comercial do jornal Gazeta da Tarde, uma trincheira impressa do movimento. Logo que desembarcou no Porto do Mucuripe, em Fortaleza, Patrocínio foi recebido por um discurso caloroso de Chico da Matilde ao som de uma banda de música. O médico João Rocha Mo- reira lhe entregou a carta de alforria de seu escravo, Antonio. Patrocínio escreveu um soneto para o jornal $O$ libertador, exaltando o gesto. Fez conferências em benefício da Libertadora Cearense, um tanto desfalcada com a compra de cartas de alforria. Em seguida, viajou em comitiva para a vila do Acarape - hoje cidade de Redenção — onde já não havia mais escravos. Em Pacatuba, José do Patrocínio discursou na companhia do Dragão do Mar.

Vieira da Cunha, narra um caso acontecido em 1886 que ilustra as intricadas relações entre a poesia de humor e a política, como diria Robert Darnton ( 2014), e os efeitos dos furos de reportagem de Paula Nei. Uma milionária de Botafogo, D. Francisca de Castro, espancou violentamente duas escravas, Eduarda e Joana. Fez uso do chicote e do ferro em brasa. Mesmo feridas, as vítimas conseguiram fugir e, por todos os efeitos da palavra, foram bater à porta do jornal Gazeta da Tarde, de Patrocínio e Nei. Revoltados, os dois resolveram levar as escravas até a Rua do Ouvidor, exibi-las nas redações para o testemunho geral. Mas Joana não resistiu às torturas, morrendo num leito da Santa Casa sobre o qual, em delírio, pedia que lhe tirassem as correntes. Paula Nei convocou os abolicionistas e preparou um velório com pompa e discurso. Quando o féretro passava em frente à residência de Francisca de Castro, Nei desafiou a ricaça a aparecer na janela. No outro dia, os jornais atacavam o chefe de polícia, pediam explicações ao imperador Pedro II, apelavam para a justiça. Francisca sentou no banco dos réus e foi absolvida. Mas não ficou por isso. Em 1887, Artur Azevedo levava o drama ao teatro de revista, desnundando toda a torpeza. A história social da cidadania no

Dossiê Literatura e Memória

Arquivos do CMD, Volume 3 N.2. Ago/Dez 2015 
${ }^{4}$ Sobre os intelectuais humoristas Manuel de Bastos Tigre e José Madeira de Freitas, o Mendes Fradique, consultar os livros Brasil pelo Método Confuso: Humor e Boemia em Mendes Fradique, de Isabel Lustosa e Raízes do Riso. A Representação Humrística na História Brasileira: da Belle Époque aos Primeiros Tempos do Rádio, de Elias Thomé Saliba.
Brasil em muito deve à face moleque do talento combativo do cearense.

Sempre à margem do repertório de obras canônicas e como que excluído do panteão de celebridades da cultura escrita, as quadrinhas improvisadas de Paula Ney eram publicadas, por assim dizer, pelo próprio público. Seu anedotário preparava o que Elias Thomé Saliba (2002) chama de "espírito da Belle Époque", fartamente ilustrado na tradição humorística da imprensa do século XIX e dos primeiros anos do século XX. Se por um lado, Nei inaugura o repertório de intelectuais-moleques, contadores de piadas que riem deles mesmos e sem culpa, como a reivindicação de uma diversidade regional; por outro, antecipa, no plano nacional, a ironia ferina de um Bastos Tigre, a irreverência de um Mendes Fradique ${ }^{4}$ típicas do período republicano. Ademais, a história social da cidadania no Brasil muito deve ao riso moleque e talento combativo do poeta cearense.

\section{Grêmios literários, um lado moleque do Ceará}

Em Fortaleza, Oliveira Paiva e Adolfo Caminha eram protagonistas de uma pujante cena literária que se expressava na publicação de folhetins, livros, pasquins, na realização de saraus e salões, e na formação de grupos com interesses para além da literatura, filosóficos e políticos (Cardoso, 2002; Oliveira Almir, 2002). Esses grupos autoproclamados "grêmios literários" buscavam uma intervenção intelectual e artística na cidade. Leonardo Mota, em A Padaria Espi- ritual (1994), de 1939, elenca trinta e seis grêmios, entre clubes, sociedades e gabinetes de leituras no Ceará, sendo vinte em Fortaleza. Três agremiações alcançaram, anos após, o reconhecimento da crítica literária nacional: a Academia Francesa (1871), o Club Literário (1886) e a Padaria Espiritual (1892).

Em Fortaleza, a experiência nas margens levavam os escritores a transitar na vida de província, importando livros e revistas, viajando e mantendo trocas de livros e cartas com amigos distantes, fazendo das necessidades impostas pela ausência de uma esfera cultural consolidada, seus trunfos e virtudes.

A Academia Francesa teve entre seus idealizadores Capistrano de Abreu, Tristão de Alencar Araripe Jr., Domingos Olímpio e Raimundo da Rocha Lima, intelectuais adeptos do positivismo de Auguste Comte, o que justifica o nome da agremiação. Defendiam os princípios do trabalho, do ajustamento social à ordem industrial-burguesa e o conhecimento científico, tomados por eles como forças transformadoras e necessárias para o progresso do Brasil rumo aos parâmetros europeus da "gente civilizada" (Cardoso, 2002). O grêmio se reunia periodicamente na casa de Rocha Lima para realizar leituras e debates sobre a filosofia de Comte. Os acadêmicos também promoviam conferências públicas e noturnas para os trabalhadores, experiência chamada de "Escola Popular", numa clara alusão à ação educativa ampliada dos homens de letras (Oliveira Almir, 2002).

O Club Literário, criado no ano de 1886, era composto por trinta e seis homens e duas mulheres. Entre os integrantes figuravam os seguintes escritores: Abel Garcia, Álvaro Martins, Ana Nogueira,

Dossiê Literatura e Memória 


\section{Andréa Borges Leão}

Francisco Secundo

Antônio Sales, Bezerra de Menezes, Francisca Clotilde, Guilherme Studart, João Lopes, Justiniano de Serpa, Juvenal Galeno, Manuel de Oliveira Paiva, Paulino Nogueira, Papi Júnior e Rodolfo Teófilo (Oliveira Claudia, 2002). O veículo divulgador do Club foi o jornal “A Quinzena”, que teve trinta números e circulou de 1887 a 1888. É possível afirmar que por viverem numa "Ilha de letrados", envolta em um "mar de analfabetos", nutria-se a crença no caráter missionário dos homens de letras (Sevcenko, 2003). Oliveira Paiva, um herói em disponibilidade, escreveu em A Quinzena, de 1887 — as "Letras" são "a melhor síntese da civilização". A ideia era a de que a ação dos escritores podia contribuir para o desenvolvimento de uma cultura letrada que tirasse o Ceará do "marasmo". No Club Literário havia algumas das figuras que formariam a Padaria Espiritual, uma das experiências de modernismo anterior à Semana de Arte Moderna de São Paulo, em 1922.

Antônio Sales e Álvaro Martins, escritores e pioneiros do Club, estavam entre os fundadores, em maio de 1892, do novo grêmio de artes e literatura, que chamou a atenção de outros intelectuais do país. Rodolfo Teófilo, ex-Club Literário, farmacêutico de ofício e escritor veio a integrar a Padaria no ano de 1894, na segunda fase do grupo. No seu Programa de Instalação com 48 artigos, o qual, segundo Leonardo Mota (1994), "foi transcrito em quase todos os jornais do Brasil", a Padaria Espiritual revelava o caráter de vanguarda moderna. No artigo 21, por exemplo, estabelece indigna de publicidade qualquer peça literária em que se falar de animais ou plantas estranhas à fauna e à flora brasileiras, como cotovia, olmeiro, rouxinol, carvalho. Sânzio de Azevedo, em nota de rodapé do livro de Leonardo Mota sobre a Padaria, lembra que a fuga de termos estrangeiros foi trinta anos após a preocupação nacionalista de Monteiro Lobato e do movimento modernista de São Paulo. Os Padeiros, como se autodenominavam os integrantes numa alusão ao trabalho intelectual de fabricação do "pão do espírito", apontavam a importância de valorizar uma cultura brasileira com raízes numa cultura popular, elegendo “os modos de vida dos habitantes dos sertões e vilarejos como definidores do caráter nacional" (Cardoso, 2006:23).

Devido ao tom jocoso e irreverente com o qual a agremiação é criada, a Padaria foi e é, por vezes, vista como propagadora da verve cearense para o humor. $\mathrm{O}$ artigo 11 do Programa de Instalação proibia aos padeiros o "tom oratório, sob pena de vaia"; e o artigo 16 obrigava-os a dizer uma "pilhéria de espírito" por semana, sob pena de pagar ao sábado café para todos. É provável, no entanto, que a associação da Padaria com a "molecagem cearense" seja uma leitura posterior ao período da existência do grêmio. Uma interpretação que serve mais para reforçar o discurso de uma "identidade cearense" do que para compreender o que foi de fato a agremiação. O que importa é que o humor na versão moleque estabelecia um elo com a vida corrente das pessoas, por isso, criava universos de sociabilidade. $\mathrm{O}$ vasto repertório de piadas dos escritores-padeiros necessitava de um público para se realizar. A apropriação dos leitores e ouvintes consistia em projetar as situações e tipos cômicos, dos quais foram fontes de inspiração, para fora das narrativas. É daí que vem a popularidade dos padeiros. Os padeiros, embora reivindicando um pertencimento regi-

Dossiê Literatura e Memória 
onal e uma diferença nacional, sabiam muito bem posicionar-se na contramão das armadilhas do folclore e do exotismo. E assim, o termo "Ceará moleque" revestia-se de comicidade.

Toda essa movimentação leva a crer que uma das saídas possíveis para expressar a vida intelectual na província eram as práticas autoreferentes do humor moleque.

\section{A literatura, vidas que imitam a arte}

Nos Romances de Oliveira Paiva e Adolfo Caminha citados no início, as alcunhas de atrasado, sem nobreza e canalha como um dos significados da molecagem eram dirigidas, na verdade, a uma parte da população fortalezense: a parcela que sonhava com uma cidade "moderna e civilizada", mas que cultivava hábitos e costumes de uma tradicional vida sertaneja. Destarte, em A Afilhada e A Normalista os autores não falam de um "povo alegre e irreverente"; a rigor, se expressam de forma preconceituosa, na sua interpretação da cidade, classificando como "gentinha atrasada e canalha aqueles que gostavam de bisbilhotar e zombar da vida alheia”. A gentinha que de tudo ria desencadeava um riso desdenhoso, sarcástico e amargo.

No número 32 do jornal $O$ Libertador, do dia 6 de fevereiro de 1889 , teve início a publicação em folhetim do romance $A$ Afilhada, de Manuel de Oliveira Paiva. Na trama, o rótulo "Ceará moleque" aparece na forma de um comentário do narrador. $\mathrm{O}$ personagem $\mathrm{Vi}$ cente, um jovem educado na capital do Império, escutava sua tia, Dona Fabiana Góis, falar sobre um tal de Visconde de São Galo. Segun- do aquela senhora, este era um nobre titular da cidade com o qual Dona Fabiana aspirava casar sua única filha, Maria das Dores. Assim, a Sra. Góis derramava elogios para o nobiliárquico futuro genro:

No meio da conversa, como era hábito seu adquirido, trazia sempre o Visconde de São Galo. Conhecia-o? O chefe da nobreza da província. Não? Digno dos nossos antepasados! O desembargador ou concordava, ou não tugia. Mas o engenheiro é que ficou embatucado.

Senhor, que nobreza era aquela no Ceará moleque?! Enfim, como não conhecia aquilo bem... (PAIVA, 1993: 188, grifos meus).

O "Ceará moleque", nesse diálogo, indica "não nobreza" e "atraso". O narrador talvez quisesse dizer: como poderia haver alguma família ou pessoa nobre naquela província? Era uma fidalguia cabeça-chata isso sim! A compreensão era de que Fortaleza nunca fora uma "cidade nobre", jamais alcançara algo como uma vida aristocrática entre as suas elites e, mesmo naquele período, com as poucas mudanças urbanas pelas quais passava, ainda estaria longe de tornar-se uma cidade "moderna e civilizada".

Três anos após a primeira aparição impressa da expressão "Ceará moleque", ela ressurge no romance A Normalista, de Adolfo Caminha, de 1893. O "Ceará moleque" possui também um sentido pejorativo e aparece na fala de um personagem que desdenha um "alcoviteiro" pasquim. Eis a intriga: a estudante da Escola Normal, Maria do Carmo, a personagem principal, reclama a Lídia, sua amiga e confidente, do pasquim A Matraca - de acordo com o narrador, "um jornaleco imundo que falava da vida alheia" - o qual escrevera versos 
sobre seu namorico com o Zuza, um estudante de Direito de Pernambuco que passava férias em Fortaleza:

Estás vendo, menina? Lê isto aqui. E apontou com o deEram uns versos de pé de viola que contavam o recente namoro do Zuza:
"A normalista do Trilho,
ex-irmã de caridade,
está caída pelo filho
dum titular da cidade
O rapazola é elegante
e usa flor na botoeira:
D. Juan feito estudante
A namorar uma freira...
Eis porque, caros leitores,
eu digo como o Bahia:
- Falem baixo, minhas flores,
Senão... a chibata chia!'

Lídia achou graça na versalhada. Ela também já saíra na Matraca. nada.

- Um desaforo, não achas? Perguntou a normalista indig-

- Que se há de fazer, minha filha? Ninguém está livre destas coisas no Ceará Moleque. Não se pode conversar com um rapaz, porque não faltam alcoviteiros (CAMINHA, 1997: 36-37, grifo do autor).

O "Ceará moleque", nesse caso, era um rótulo para indicar aqueles que prestavam atenção na vida alheia e que insultavam com os outros. Era no que basicamente se constituía, para Adolfo Caminha, o "canalhismo de Província".

De outro modo, o epíteto aparece no enredo da novela $U m$

Motim na Aldeia, de Araripe Júnior, ambientada no final do século
XVIII, no tempo que o Brasil era Colônia de Portugal, na antiga Vila do Forte - como era chamada a cidade de Fortaleza durante a dominação portuguesa. $\mathrm{O}$ narrador, em linhas gerais, relata um caso pitoresco envolvendo o conflito entre a autoridade do governo colonial, o Capitão Mor Féo e Torres, e a população liderada por um açougueiro, o Fagundes. O nó da intriga é a reação à derrubada de um cajueiro da cidade. Note-se que esta ficção é baseada em registros históricos verídicos. Segundo Braga Montenegro (1975), no prefácio d'O Cajueiro do Fagundes, novo título da novela, Araripe Júnior teria extraído a substância de sua narrativa de uma monografia do historiador Barão de Studart a respeito de um dos capitães-mores da capitania, cadete das forças militares portuguesas.

$\mathrm{Na}$ novela, o insurgente açougueiro Fagundes é apresentado como "capadócio de marca" e "língua afiada", engenhoso na pilhéria. $\mathrm{O}$ açougueiro teria sido um dos primeiros moleques da história do “Ceará moleque”. A expressão carrega o mesmo sentido de canalhice que possui no romance de Adolfo Caminha. Mas, há uma diferença crucial: n'O Cajueiro do Fagundes o apelido é tomado como parte de uma tradição cearense. O autor, Araripe Júnior, além de querer indicar os canalhas e patifes que viviam na antiga capitania do Ceará, cava os alicerces do epíteto baseando-o numa teoria da mestiçagem como instabilidade da raça. Vejamos:

Fagundes, pois, pertencia a esse gênero de gente, que, pelos tempos adiante, se alcunhou de Ceará-moleque. O Cearámoleque é a encarnação de todas as qualidades elementares resultantes da mestiçagem, não só física, mas também moral, da plebe cearense. Alegres, audaciosos, despreocupados, mofando de tudo, 
pertinazes, os cearenses dessa origem, com os seus hábitos sertanejos, quando perseguidos pelas intempéries, pelo tufão da desventura, hibernam, mas não sucumbem. É possível que na confecção dessa resistência de faquires, tenham andado por muito as crises climáticas das secas. Todo homem nascido naquelas regiões é, em regra, de temperamento periódico: ora abundância, ora penúria. Contudo o fôlego sempre alerta (ARARIPE JR., 1975: 80, grifo do autor).

A ideia segundo a qual certa "irreverência inata" se associa ao "povo cearense" aparece colada à denominação em foco no romance de Araripe Júnior. N'O Cajueiro do Fagundes inaugura-se o mito de que "todo cearense é moleque por natureza", pelas qualidades elementares resultantes da mestiçagem. Essa mitificação implica na interpretação sobre "o que faz ser cearense", acionando valores e avaliações retomadas por aqueles que pretenderam (ou pretendem) descrever a "identidade moleque do povo do Ceará". O "Ceará moleque", de Araripe Júnior, ainda se refere à canalha e ao atraso. No entanto, é exposta a ideia de que por causa da mestiçagem "física e moral" e devido à resistência criada em resposta às intempéries climáticas - “[...] os cearenses dessa origem, com os seus hábitos sertanejos, quando perseguidos pelas intempéries, pelo tufão da desventura, hibernam, mas não sucumbem". Quer dizer, a "plebe cearense" é "alegre e audaciosa" por natureza. As secas que assolaram o Ceará desde suas origens e a mestiçagem, assim, justificariam a molecagem de seu povo. Enfim, o cearense seria tradicionalmente moleque porque é uma "raça" mestiça que não sucumbe, mas que resiste às adversidades.
Não se pode desconhecer a relação de um poeta como Paula Nei com o humorismo nas caricaturas dos jornais no período imperial. O cômico tolerado no século XIX tinha como principal veículo de difusão a imprensa, como sugere Elias Thomé Saliba (2002). A irreverência e as blasfêmias do cearense Paula Nei na corte carioca ensejavam um riso aceito por todos, o que, na província certamente seria recebido como traço positivo do "Ceará moleque".

Já com Oliveira Paiva e Adolfo Caminha o "Ceará moleque" torna-se estigma que deteriora uma identidade e torna-se objeto de censura, como sugere Goffman (1988) e, como define Alain Deligne (2011: 30), provoca um riso que "faz o objeto sofrer um tratamento e prossupõe um julgamento de valor”. Pecha para a falta de nobreza e o canalhismo de província, coisa do "povinho", dos "pés-de-poeira", típico dos moradores da periferia de Fortaleza. Somente com Renato Sóldon o estigma torna-se emblema e a molecagem ganha definição de fina ironia, sátira procaz, gênio inquieto, adágio para intelectuais com espírito irreverente.

Hora "coisa da arraia miúda", hora irreverência intelectual, o "Ceará moleque", certamente, adquire significados concorrentes que circulam em todos os âmbitos da estrutura social. Herman de Castro Lima (1997) em livro de crônicas e memórias sobre Fortaleza de seus tempos de menino, nas duas primeiras décadas do século XX, intitulado Imagens do Ceará (1954), indica que este espírito irreverente, sob o rótulo de moleque serve tanto para o "letrado" como para o "homem da rua". Nas palavras de Hermam Lima identificamos os 


\section{Andréa Borges Leão}

\section{Francisco Secundo}

esforços de construção de traços positivos da cearensidade como autoimagem da molecagem (1997:135-136):

Os reflexos desse espírito, que tanto se compraz nos torneios da criação literária em prosa e verso, no romance e no conto, na crônica, no jornal, como na especulação da crítica, da matemática e das concepções doutrinárias, aí estão, por sua vez, na colheita de ditos e conceitos de patrícios nossos, dum sentido que vai da farpa aguçada e ferina à pura chispa do melhor humour parisiense, pontilhado aqui e ali dum grão de sabedoria a que não é alheio certo prestígio, de fato, encantatório. Espírito que varia da ironia mais viva e pungente à sátira procaz, da simples anotação humorística ao pitoresco dum rótulo definitivo para homens e coisas. Não é dos menores por certo, ao contrário do que pareça, o título de Ceará Moleque, tantas vezes lançado pejorativamente ao mesmo berço de Alencar, em contraposição aos outros apelativos de Terra da Luz e Terra de Sol. Nem há porque se desdenhe dum gênero em que tanto se requer de sutileza intelectual, vivacidade malícia, seja no reparo do letrado, seja na chispa de gênio tantas vezes anônimo do povo, pois nele se compraz tanto o poeta ou o romancista de renome, como o cantador de improvisos ou o próprio homem da rua.

Com a mesma insolência de Paula Nei, que ria de tudo e de todos, o escritor Quintino Cunha equilibrava-se na balança da formalidade e informalização dos comportamentos de inícios do século XX. Cunha é personagem célebre na história do Ceará por suas pilhérias, causos e ditos chistosos. Suas práticas de humor são narradas pelos filhos Plautus Cunha e Lourdite Cunha nos livros Anedotas do Quintino (1954) e Quintino Cunha no conceito de seus contemporâneos (1955). No livro Quintino Cunha, de Francisco José Souza (2002), lêse: "Ninguém em toda nossa história encarou melhor o jeito 'moleque de ser' cearense do que Quintino Cunha".

\section{Conclusão}

\section{Uma pitada de humor e outra de teoria}

Há mais de cem anos que aos cearenses é dada a alcunha de "povo moleque". As simultâneas, sucessivas e concorrentes definições do epíteto dizem que o cearense possui um espírito irreverente e galhofeiro cultivado coletivamente. E comprovando tal assertiva é notório nos últimos vinte anos o sucesso nos meios de comunicação nacionais de humoristas oriundos do Ceará. A noção mais ou menos difundida socialmente é a de que o estado abriga um celeiro de artistas do humor porque, na verdade há, em cada cidadão, um "humorista nato". Procuramos mostrar como sociogênese desta ideia encontra-se na produção literária de finais do século XIX. A partir daí, a versão particular do humor cearense, que também reivindica um caráter nacional, entra em disputa com outras versões regionais do humor, por exemplo, dos personagens Jeca Tatu, de Monteiro Lobato, e Macunaíma, de Mário de Andrade, outros modelos do cômico, da sátira e do grotesco.

Discutimos o modo como a ficção transmite ideias e conceitos e como a temática moleque é construída tanto nos enredos e personagens da literatura, como na atuação dos escritores e na circulação de suas obras por diversos grupos e níveis da hierarquia social. É interessante notar que a indústria do entretenimento que se configura em Fortaleza a partir dos anos 1980 não elege a literatura e a produção impressa como alvos dos negócios, mas a declamação de piadas e performances artísticas em shows de humor em bares, pizzarias e 
Matéria intitulada "O Boom do Humorismo de Bar", jornal O Povo, Fortaleza, Caderno B p. 2, 22 jul. 1990; assinada por Jackson Araújo e Tininha Magalhães.

\section{Andréa Borges Leão}

Francisco Secundo

barracas de praia. Desde então uma onda de artistas e espetáculos humorísticos destinados para atração turística toma conta das noites fortalezenses. Este modelo de negócio atualiza e resignifica as práticas dos folhetinistas orais do século XIX.

Em 1986, o ator Paulo Diógenes deu o pontapé inicial para o negócio dos shows humorísticos. Diógenes fora convidado para apresentar, em um bar próximo à orla marítima da cidade, trechos de uma comédia em cartaz no teatro. No ano de 1988, o Pirata Bar, localizado na Praia de Iracema, exibe apresentações musicais no estilo irreverente com o hoje célebre humorista Marcondes Falcão Maia, o "brega star" Falcão. Junto a este, em 1989, surgem em um Festival de Música Brega promovido pelo Pirata Bar, outros artistas, como Lailtinho Brega, Rossicléa e Meirinha. Desde então, os espetáculos de humor destinados ao público local e inscritos nas programações turísticas dão o tom das noites fortalezenses.

Alguns desses profissionais leram as obras sobre a cultura moleque, como os já citados livros de Plautus Cunha e Lourdite Cunha sobre o irreverente pai, Quintino. Falcão não só leu, tudo indica que fez bom uso, da literatura moleque. Desde o início da carreira, Falcão busca associar a "tradicional molecagem cearense" ao movimento de profissionais do humor nas noites da capital. No mencionado texto, publicado no jornal O Povo, em 1990, Falcão, já autodenominado "brega star", lembra os saudosos "grupos de moleques" de antanho.

As práticas lúdico-artísticas dos humoristas do Ceará passam a constituir-se num ramo das atividades propiciadas pelo mecanismo institucional do entretenimento-turismo, para ficarmos com o soció- logo Edson Farias (2011). Ao lado do show de humor, essas práticas alinham outros atrativos culturais tomados como próprios do Ceará ou do nordeste - a culinária típica e o forró "pé de serra". Humor, forró e iguarias "exóticas" funcionam como reivindicações de uma diversidade local e acabam tornando-se atividades "voltadas para a prestação de serviços de diversão e turismo" situadas "nos fluxos translocalizados dos símbolos" (Farias, 2011: 15). O humor do Ceará, alcançando a posição de prática lúdico-artística, passa a ser produto de cultura e entretenimento destinado ao turismo e acaba ocasionado uma reorganização e/ou atualização da "cultura da molecagem".

A associação entre a tradicional molecagem cearense e esses profissionais do humor é operada, desde o início, tanto pelos meios de comunicação locais como por eles próprios. Na matéria publicada em 1990, lê-se: "Rir sempre foi um grande programa. O Ceará, aliás, registra na sua história personagens que fizeram da molecagem uma forma de expressão. [...] o certo é que o humor está dando muito trabalho para atores e cantores em Fortaleza",

Cabe, enfim, precisar que as instâncias de produção do Ceará moleque, hoje, encontram-se massivamente disseminadas. Essas instâncias podem ou não comunicar-se diretamente entre si, mas acabam formando uma rede de intertextualidade cômica. Lembramos a série de referências comuns às práticas de humor, aos cordéis, ao cinema e aos programas televisivos do gênero. As definições de longo prazo de que se reveste o termo Ceará moleque hoje marcam presença nos logos de camisetas - um jeito de falar cearense (arrocha o nó, eita macho, armaria); nas piadas de "corno" (os mói de chifre) e na ainda 
atual "vaia cearense" (novas versões dos mexericos e maledicências?); nos ditos e causos do Sr. Lunga, lendário matuto da cidade de Juazeiro do Norte; até nos modos de falar da juventude das periferias de Fortaleza (os negos, os chapa, os muito doido). Há elementos componentes de um humor com a marca do popular e que é apropriado por uma rede do mecanismo institucional do entretenimentoturismo (FARIAS, 2011) de uma Fortaleza moleque.

\section{Referências}

ARAÚJO, J. MAGALÃES, T. Jornal $O$ Povo. Matéria: $O$ Boom do Humorismo de Bar. Fortaleza, Caderno B, P. 2. 22 de julho, 1990.

ARARIPE JR., T. de A. O Cajueiro do Fagundes (Episódio Cearense). Fortaleza. Editora Henriqueta Galeno/Secretaria de Cultura, Desporto e Promoção Social, 1975.

AZEVEDO, S. de. Adolfo Caminha (Vida e Obra). $2^{\mathrm{a}}$ ed., revista Fortaleza: EUFC, 1999.

CAMINHA, A. A Normalista. Fortaleza: Diário do Nordeste, 1997.

CARDOSO, G. P. Literatura, imprensa e política (1873-1904). In: S SOUZA, F. de C. NEVES (Org.). Intelectuais. Fortaleza: EDR, p. 41 $72,2002$.

Padaria Espiritual: biscoito fino e travoso. $2^{\mathrm{a}}$ ed. Fortaleza: Museu do Ceará/Secretaria da Cultura do Estado do Ceará, (2006).

COELHO, N. A conquista. 2. Ed. Porto: Livraria Chardron, 1913.

CUNHA, C. V. No Tempo de Paula Ney. São Paulo: Edições Saraiva, 1949.
DARNTON, R. Poesia e Política. Redes de comunicação na Paris do século XVIII. São Paulo: Companhia das Letras, 2014.

ELIAS, N. O Processo Civilizador. Uma História dos Costumes. Rio de Janeiro: Zahar, 1990.

\& DUNNING, E. Deporte y ocio en el proceso de la civilización. Fondo de Cultura Económica. México, 1996.

DELIGNE, A. De que maneira o riso pode ser considerado subversivo? In: I. LUSTOSA (Org.). Imprensa, Humor e Caricatura. A questão dos esteriótipos culturais. Belo Horizonte: Editora UFMG. P. $29-46,2011$

FARIAS, E. S. Ócio e Negócio: festas populares e entretenimentoturismo no Brasil. Curitiba: Editora Appris, 2011.

GOFFMAN, E. Estigma: notas sobre a manipulação da identidade deteriorada. $4^{\mathrm{a}}$ ed. Rio de Janeiro: Guanabara, 1988.

LIMA, H.. Imagens do Ceará. $2^{\circ}$ ed. Fortaleza: UFC - Casa José de Alencar Programa Editorial, 1997.

LIMA, Z. M. de M. A cidade de Fortaleza na literatura do século XIX. In: Souza, Simone e Neves, Frederico de Castro (Org.). Comportamento. Fortaleza: EDR, p. 39-58, 2003.

LUSTOSA, I. Brasil pelo método confuso: boemia e humor em Mendes Fradique. Rio de Janeiro: Editora Bertrand Brasil, 1993.

MAGAlHÃES, JR. R. A Vida Tirbulenta de José do Patrocínio. Rio de Janeiro: Editora Sabiá, 1969.

MENEZES, R. de. A Vida Boêmia de Paula Ney. São Paulo: Livraria Martins Fontes, 1944.

MONTENEGRO, T. Oliveira Paiva. Fortaleza, Edições Demócrito Rocha, 2003. 
MOTA, L. A Padaria Espiritual. $2^{\text {a }}$ ed. Fortaleza: UFC/Casa José de Alencar, 1994.

OLIVEIRA, A. L. Universo letrado em Fortaleza na década de 1870. In: SOUZA; F. de C. NEVES (org.). Intelectuais. Fortaleza, EDR, p. $15-40,2002$.

OLIVEIRA, C. F. de. As ideias científicas do século XIX no discurso do Club Literário. In: SOUZA; F. de C. NEVES (org.). Intelectuais. Fortaleza, EDR, p. 73-96, 2002.

PAIVA, M. de O. Obra Completa. Rio de Janeiro: Graphia Editorial, 1993.

PONTE, S. R. Fortaleza Belle Époque: reforma urbana e controle social (1860-1930). Fortaleza: edições Demócrito Rocha, 2001.

PONTES, E. A Vida Exuberante de Olavo Bilac. Rio de Janeiro: Livraria José Olympio, 1944.

SALIBA, E. T. Raízes do Riso. A Representação Humorística na História Brasileira: de Belle Époque aos primeiros tempos do rádio. São Paulo: Companhia das Letras, 2002.

SEVCENKO, N. Literatura como Missão: tensões sociais e criação cultural na Primeira República. 2ed. São Paulo: Companhia das Letras, 2003.

SILVA, M. A. F. da. Uma Fortaleza de risos e molecagem. In: S. SOUZA; F. de C. NEVES (org.). Comportamento. Fortaleza: EDR, p. $17-38,2003$.

SÓLDON, R. Ceará Moleque (humorismo cearense). Fortaleza: Ed Silveira Marinho \& Cia. (Acervo do setor de Obras Raras da Biblioteca Pública Governador Menezes Pimentel), 1936.

SOUZA, F. J. Quintino Cunha. Fortaleza: Edições Demócrito Rocha 2002.
WOUTERS, C. Informalization. Manners \& emotions since 1890. London: Sage Publications, 2007. 